\title{
Therapeutic Potential of Extracellular Vesicles for the Treatment of Nerve Disorders
}

\author{
Luisa R. Galieva ${ }^{1}$, Victoria James ${ }^{2}$, Yana O. Mukhamedshina ${ }^{1,3 *}$ and Albert A. Rizvanov ${ }^{1}$ \\ ${ }^{1}$ Institute of Fundamental Medicine and Biology, Kazan Federal University, Kazan, Russia, ${ }^{2}$ School of Veterinary Medicine and \\ Science, University of Nottingham, Nottingham, United Kingdom, ${ }^{3}$ Department of Histology, Cytology, and Embryology, \\ Kazan State Medical University, Kazan, Russia
}

\section{OPEN ACCESS}

Edited by:

Grant Thomas Corbett, Harvard Medical School, United States

Reviewed by:

Susanna Amadio,

Fondazione Santa Lucia (IRCCS), Italy Veronica Perez de la Cruz,

Instituto Nacional de Neurología y Neurocirugía (INNN), Mexico

*Correspondence:

Yana O. Mukhamedshina yana.k-z-n@mail.ru

Specialty section:

This article was submitted to

Neurodegeneration,

a section of the journal

Frontiers in Neuroscience

Received: 20 November 2018

Accepted: 12 February 2019

Published: 05 March 2019

Citation:

Galieva LR, James $V$

Mukhamedshina YO and Rizvanov AA (2019) Therapeutic Potential of

Extracellular Vesicles for the Treatment of Nerve Disorders.

Front. Neurosci. 13:163. doi: 10.3389/fnins.2019.00163
The use of extracellular vesicles (EVs) as cell free therapy is a promising approach to stimulate tissue regeneration including that of the nervous system. EVs transfer bioactive proteins and lipids, RNA and microRNAs, which play a relevant role in EV-mediated intercellular communication. The immunomodulatory, anti-inflammatory, and neuroprotective effects of mesenchymal stem cells-derived EVs have been well studied, knowledge of this paracrine mechanism and the availability of these cells, positions mesenchymal stem cells as a potential source of EVs for cell free therapy for a variety of regenerative and nervous system disorders. In this review, we focus on the immunomodulatory and neuroprotective effects of stem cells-derived EVs within in vitro and in vivo models of nerve disorders.

Keywords: extracellular vesicles, immunomodulatory effects, neuroprotective effects, mesenchymal stem cells, nerve disorders

\section{INTRODUCTION}

The need to improve the effectiveness of available therapeutic protocols used within the regenerative medicine field, has led to a number of different approaches. However, the nerve disorders still present a treatment challenge due to the low regenerative potential of the central nervous system (CNS). Stem cell therapy has been at the forefront of regenerative medicine for the last decade, but poor clinical trial reports have shifted the focus of researchers to develop improved protocols and complementary approaches. For example, it became apparent, that the therapeutic effect of stem cells can be enhanced through the expression of genes of neurotrophic factors using gene therapy approaches. Unfortunately, a hazard associated with inducing such genetic changes is the potential for stem cell transformation. Therefore, a critical need still exists for the development of new therapeutic approaches that do not carry the same potential risks.

Confirmation of the paracrine effects of stem cells and the relevance to tissue regeneration was a breakthrough in this area, paving the way for a series of subsequent studies to characterize and leverage this mechanism for therapeutic development. Gnecchi et al. were the first to show that conditioned medium from mesenchymal stem cells (MSCs) overexpressing the gene Akt1 exerted cytoprotective effects on cardiomyocytes exposed to hypoxia in vitro, reduced acute myocardial infarction sizes and improved ventricular functions in vivo (Gnecchi et al., 2005, 2006). Takahashi et al. (2006) similarly found that injection of bone marrow mononuclear cells supernatants increased microvessel density and decreased the fibrotic area within an infarcted heart model, contributing to significant functional improvement. Subsequently, MSCs-derived conditional medium was reported to stimulate functional and morphological improvement in pathological conditions such as renal injury, myocardial infarction, and fulminant hepatic failure (Bi et al., 2007; Parekkadan et al., 2007; Timmers et al., 2007). 
The results obtained supported a paracrine hypothesis of stem cell action in tissue protection and repair. It was subsequently established that these beneficial were attributable to soluble factors including extracellular vesicles (EVs) released from stem cells (Bruno et al., 2009; Lai et al., 2010; Xin et al., 2013a). The biogenesis and methodology of isolation of EVs has been described in several published reviews (Biancone et al., 2012; Akers et al., 2013; Koniusz et al., 2016). Therefore, in this mini review, we focus on the newly emerging field investigating the therapeutic potential of stem cell-derived EVs, produced in vitro and transplanted within the animals and patient for the treatment of nerve disorders.

\section{IMMUNOMODULATORY AND NEUROPROTECTIVE EFFECTS OF STEM CELL-DERIVED EVS}

By transferring bioactive proteins and lipids, RNA and microRNAs (miRNAs), EVs may play a crucial role in intercellular communication between stem cells and other cells within the tissue micro-environment (Camussi et al., 2013; Braccioli et al., 2014; Gomzikova and Rizvanov, 2017). The antiinflammatory and neuroprotective effects of MSC-derived EVs and their paracrine mechanism of action have been well studied (Kalani et al., 2014; Börger et al., 2017).

EVs have been shown to be actively involved in processes of immune regulation such as stimulation of T-cell proliferation, apoptosis induction in activated cytotoxic T-cells, differentiation of monocytes into dendritic cells and B lymphocyte-mediated tumor suppression (Bobrie et al., 2011; Chaput and Théry, 2011; Taylor and Gercel-Taylor, 2011). It is not surprising that MSCs-derived EVs were also found to be immunologically active (Blazquez et al., 2014; Zhang et al., 2014; Bruno et al., 2015). The immunomodulatory properties of MSCs-derived EVs are reported to be the result of the suppression of TNF-a and IL- $1 b$ secretion, increasing the concentrations of TGF-b, regulatory $\mathrm{T}$ cells (Treg) and cytotoxic $\mathrm{T}$ lymphocyte-associated protein 4 , inducing Th1 to Th2 cell conversion, reducing IFN$\gamma$ production and the potential of $\mathrm{T}$ cells to differentiate into Th17 cells (Mokarizadeh et al., 2012; Blazquez et al., 2014; Del Fattore et al., 2015; Chen et al., 2016b). However, some data indicate a lower in vitro immunomodulatory effect of MSCderived EVs on T-cell proliferation and antibody formation, as compared with their cellular counterpart (Conforti et al., 2014). In a recent study, immunomodulatory effect inflammationstimulated (TNF- $\alpha$ and IFN- $\gamma$ ) MSCs-derived EVs was evaluated (Harting et al., 2018). It was found, that thus obtained EVs have enhanced anti-inflammatory properties partially due to COX2/PGE2 pathway alteration.

Although EVs can exhibit a variety of different protein and nucleic acid cargos, their regenerative effects are mainly ascribed to the transfer of specific proteins and miRNAs (Collino et al., 2017). For example, EV cargos of miR-1000, miR133b, miR-21, miR-34a, and miR-219 have been reported to exert a neuroprotective effect by regulating glutamate release at the synapse (Verma et al., 2015), promoting neural plasticity
(Xin et al., 2013b), suppressing apoptosis (Ma et al., 2013; Vallabhaneni et al., 2015), and enhancing myelination (Pusic and Kraig, 2014b).

Despite knowledge of the function of some aspects of the EV cargo, further studies are required to fully understand the mechanisms that underpin the immunomodulatory and neuroprotective effects of EVs.

\section{CURRENT PERSPECTIVES OF EVS IN THE TREATMENT OF NERVE DISORDERS}

Although the therapeutic potential of EVs has not been fully elucidated, their use can be said to be most promising for the treatment of different disorders of the CNS, when drugs are of limited use due to their inability to penetrate the blood-brain barrier (BBB). EVs have been proposed to be transported across the interior of a cell via transcytosis, which may enable these EVs to cross the BBB. This has been experimentally confirmed, as EVs given intravenously (Alvarez-Erviti et al., 2011) or intranasally (Zhuang et al., 2011; Haney et al., 2015) were able to penetrate the BBB.

It should be noted that the therapeutic potential of EVs depends on the composition of their cargo. The cargo of EVs from different cell types can include a common set of biological molecules (nucleic acids, proteins, and lipids) and also molecules that reflect the cell source of the EVs and the physiological or pathological state of the cell source (Zhang et al., 2016; Reiner et al., 2017). In this regard, it is important to define the cargo of stem cell-derived EVs to further understand the mechanisms involved in regenerative processes during therapy. Currently, most studies evaluating the regenerative potential of stem cellderived EVs focus on a general assessment of therapeutic efficacy without detailing the multiple physiological or biochemical changes occurring due to EVs specific cargo. Defining the EV cargo would allow subsequent manipulation, combining a specific set of proteins and RNAs which could efficiently modulate the course of nerve disorders (Selmaj et al., 2017).

The introduction of $\mathrm{EV}$ use into clinical practice has been limited by the ability to isolate sufficient EVs from culture systems and the heterogeneity of the cargo of naturally occurring EVs. Therefore, methods of obtaining "modified" $\mathrm{EV}$ have become a major focus for the field. In such a cases, EVs are most often derived from MSCs owing to the availability of these cells and the presence of positive properties mediated by their EVs, or induced pluripotent stem cells (iPS cells) whose EVs also demonstrate consistent regenerative abilities. EVs from both cell types have been proposed as a potential starting point for cell free therapy in nerve disorders (Figure 1).

Table 1 provides a summary of preclinical studies of EV use in both in vitro and in vivo models of nerve disorders.

\section{Multiple Sclerosis (MS)}

The success of remyelinating therapy in MS is mostly attributed to dendritic cell (DCs)-derived EVs (Pusic et al., 2014a), whereby EVs produced by IFN- $\gamma$-stimulated DCs increased 


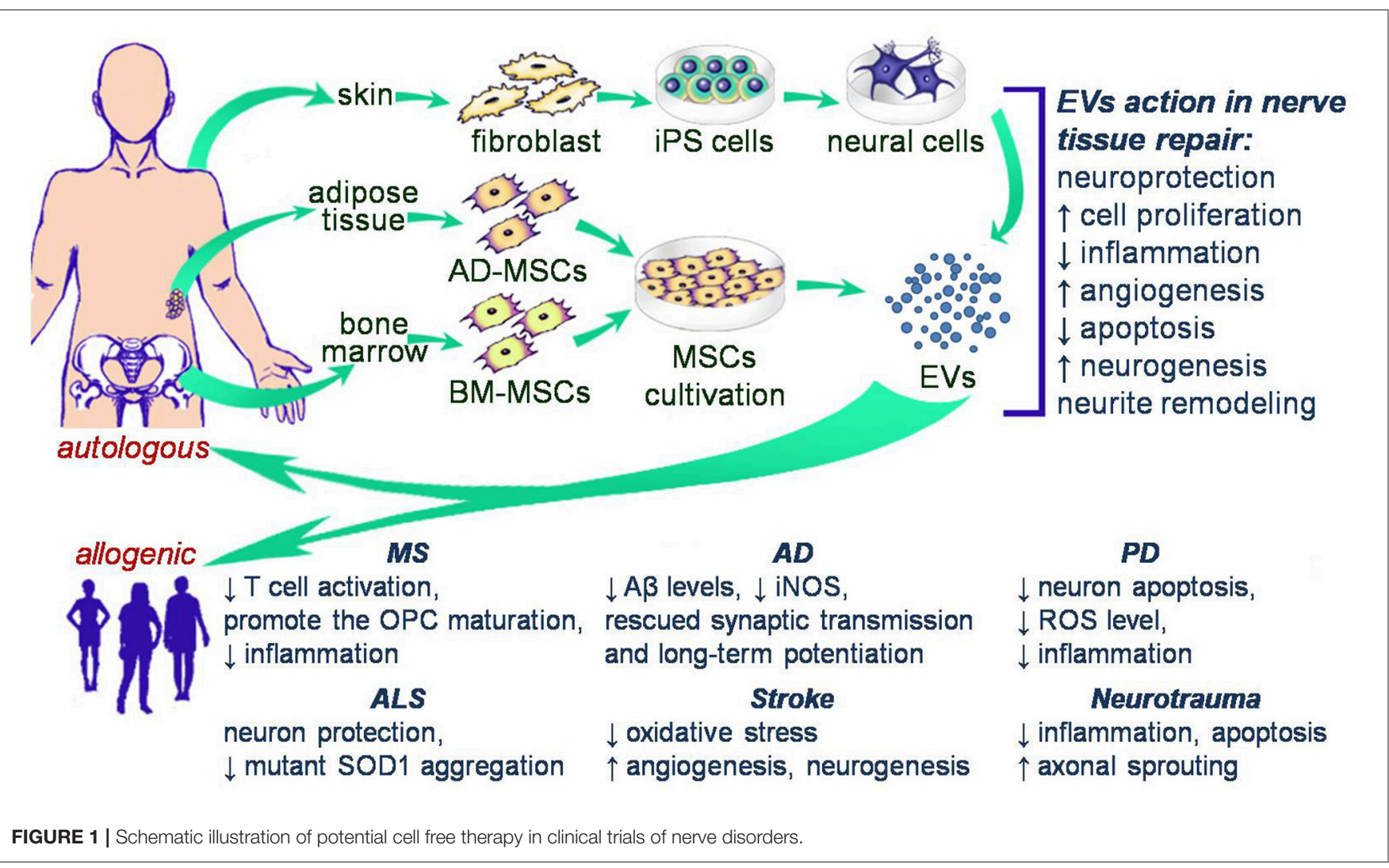

myelination and oxidative tolerance in vitro and in vivo (Pusic et al., 2014c). These changes are likely attributable to the high levels of miR-219 within the EVs, which is necessary and sufficient for oligodendrocyte precursor cell (OPC) differentiation, the formation and maintenance of compact myelin, and is deficient in human multiple sclerosis lesions (Junker et al., 2009; Dugas et al., 2010; Zhao et al., 2010). Pusic et al. (2014a) proposed that stimulated DCs-derived EVs contain high levels of specific anti-inflammatory miRNAs that may have an immunomodulatory role in suppressing the development of multiple sclerosis. Yu et al. (2013) demonstrated that EVs with membrane-associated TGF- $\beta 1$ from gene-modified DCs prevented the de novo differentiation of Th17 cells by inhibiting DC IL-6 production, and were effective in inhibiting the development and progression of experimental autoimmune encephalomyelitis (EAE).

Zhuang et al. (2011) used EVs loaded with anti-inflammatory agents like curcumin or JSI124 for intranasal delivery to the brain. Effects of this route of delivery were evaluated in 3 different inflammation-mediated murine disease models: brain tumorbearing, lipopolysaccharide (LPS)-induced brain inflammation, and EAE. Having given EVs with curcumin, mice were protected from LPS-induced brain inflammation and progression of EAE, brain tumor-bearing mice also showed a significant delay in brain tumor growth following curcumin loaded EV treatment. Intranasal administration of EVs has been shown to provide rapid transport to the brain, and subsequent absorption by the microglia.
A marked reduction in MS and EAE relapses have been observed during pregnancy (Confavreux et al., 1998). It was demonstrated in a mouse model of EAE that serum EVs suppressed $\mathrm{T}$ cell activation, promoted the maturation of OPC, and pregnancy-associated exosomes facilitated OPC migration into active CNS lesions (Williams et al., 2013). At the same time, serum EVs derived from non-pregnant mice were also able to reduce the severity of EAE. Thus, it was established that serum EVs are a prominent mediator both of immune modulation and neuroprotection which is especially pronounced during pregnancy.

\section{Alzheimer's Disease (AD)}

Wang et al. (2017) demonstrated the positive effect of using bone marrow MSC-derived EVs (BM-MSC-derived EVs) both in vitro and in vivo. Inducible nitric oxide synthase (iNOS) mRNA and protein levels were significantly reduced in cultured primary neurons prepared from APP/PS1 pups treated with BM-MSCderived EVs. In vivo studies demonstrated improved cognitive behavior, rescued CA1 synaptic transmission, and long-term potentiation in APP/PS1 mice administrated with BM-MSCderived EVs through an intracerebroventricular (i.c.v.) injection.

It has already been reported, that neutral endopeptidase (NEP) levels and activity are reduced in patients with AD (Yasojima et al., 2001). NEP was initially identified as a regulator of the A $\beta$ level (Iwata et al., 2000). Katsuda et al. (2013) demonstrated NEP-specific enzyme activity could be exhibited by adipose tissue-derived MSC EVs (AD-MSC-derived EVs). Furthermore, 
TABLE 1 | Preclinical trials using EVs.

\begin{tabular}{|c|c|c|c|c|}
\hline Disease model & Source of EVs & Protocol details & Reported effects & Reference \\
\hline \multicolumn{5}{|l|}{ MULTIPLE SCLEROSIS } \\
\hline EAE in mice & $\begin{array}{l}\text { EVs from bone } \\
\text { marrow-derived DCs } \\
\text { infected Ad/mTGF- } 1 \text { or } \\
\text { Ad/sTGF- } \beta 1 \text {, } \\
\sim 100 \mathrm{~nm}\end{array}$ & $10 \mu \mathrm{g} \mathrm{EVs/mouse,} \mathrm{intravenously}$ & $\begin{array}{l}\text { Prevented the de novo differentiation } \\
\text { of Th17 cells via inhibiting IL- } 6 \\
\text { production, inhibited the development } \\
\text { and progression of EAE }\end{array}$ & Yu et al., 2013 \\
\hline Primary OPC cultures & $\begin{array}{l}\text { serum-derived EVs of } \\
\text { pregnant and non-pregnant } \\
\text { mice }\end{array}$ & $\begin{array}{l}\text { Co-culture of primary OPC with EVs, } \\
\text { for } 72 \mathrm{~h}\end{array}$ & Enhanced the function of OPCs & $\begin{array}{l}\text { Williams et al., } \\
2013\end{array}$ \\
\hline EAE in mice & $\sim 100 \mathrm{~nm}$ & $\begin{array}{l}40 \mu \mathrm{g} \text { total protein of EVs/mouse, } \\
\text { intravenously }\end{array}$ & $\begin{array}{l}\text { Suppressed T cell activation, } \\
\text { promoted the maturation of OPC, } \\
\text { facilitated OPC migration into active } \\
\text { CNS lesions }\end{array}$ & \\
\hline $\begin{array}{l}\text { Brain tumor-bearing mice } \\
\text { model }\end{array}$ & $\begin{array}{l}\text { Tumor cells-derived EVs } \\
\text { with circumin or JSI124, } \\
\sim 100 \mathrm{~nm}\end{array}$ & $\begin{array}{l}12.5 \text { pmol EVs, intranasally for } 12 \\
\text { consecutive days }\end{array}$ & $\begin{array}{l}\text { Significantly delayed brain tumor } \\
\text { growth in the brain tumor model; } \\
\text { protected against LPS-induced brain } \\
\text { inflammation and the progression of } \\
\text { EAE }\end{array}$ & $\begin{array}{l}\text { Zhuang et al., } \\
2011\end{array}$ \\
\hline $\begin{array}{l}\text { LPS-induced brain } \\
\text { inflammation }\end{array}$ & & $\begin{array}{l}1.5 \mathrm{nmol} E V s \text { in } 10 \mu \mathrm{l} \mathrm{PBS} / \text { mouse, } \\
\text { single intranasal administration }\end{array}$ & & \\
\hline EAE in mice & & $\begin{array}{l}1.5 \mathrm{nmol} E \mathrm{EV} \text {, intranasally for } 26 \\
\text { consecutive days }\end{array}$ & & \\
\hline \multicolumn{5}{|l|}{ ALZHEIMER'S DISEASE } \\
\hline N2a cells & $\begin{array}{l}\text { AD-MSC-derived EVs, } \\
\sim 100-200 \mathrm{~nm}\end{array}$ & $\begin{array}{l}\text { Co-culture of N2a cells with EVs, } 500 \\
\mu \mathrm{g} \text { protein/mL, up to } 24 \mathrm{~h}\end{array}$ & $\begin{array}{l}\text { Decreased extracellular and } \\
\text { intracellular A } \beta \text { levels in N2a cells }\end{array}$ & $\begin{array}{l}\text { Katsuda et al., } \\
2013\end{array}$ \\
\hline APP transgenic mice & $\begin{array}{l}\text { Primary neuron } \\
\text { culture-derived EVs }\end{array}$ & $\begin{array}{l}2 \mathrm{mg} \text { total protein of EVs/ml PBS by } \\
\text { Alzet minipump at } 0.25 \mathrm{I} / \mathrm{h} \text { for } 14 \\
\text { days. }\end{array}$ & $\begin{array}{l}\text { decreased } A \beta \text { and amyloid } \\
\text { depositions }\end{array}$ & $\begin{array}{l}\text { Yuyama et al., } \\
2015\end{array}$ \\
\hline $\begin{array}{l}\text { Primary cortical neuron } \\
\text { culture from newborn } \\
\text { APP/PS1 mice }\end{array}$ & $\begin{array}{l}\text { BM-MSC-derived EVs, } \\
\sim 100-140 \mathrm{~nm}\end{array}$ & $\begin{array}{l}\text { Co-culture of cortical neurons with } \\
\text { EVs, } 100 \mu \mathrm{g} / \mathrm{ml} \mathrm{EVs} \mathrm{for} 12 \mathrm{~h}\end{array}$ & $\begin{array}{l}\text { Reduced } A \beta \text { induced iNOS } \\
\text { expression in primary neurons }\end{array}$ & Wang et al., 2017 \\
\hline APP/PS1 mice & & $\begin{array}{l}100 \mu \mathrm{g} \text { EVs in } 5 \mu \mathrm{l} \text { PBS/mouse, i.c.v. } \\
\text { injection once per } 2 \text { days for } 2 \text { weeks }\end{array}$ & $\begin{array}{l}\text { Improved cognitive behavior, rescued } \\
\text { impairment of CA1 synaptic } \\
\text { transmission, and long-term } \\
\text { potentiation }\end{array}$ & \\
\hline \multicolumn{5}{|l|}{ PARKINSON'S DISEASE } \\
\hline $\begin{array}{l}\text { 6-OHDA induced apoptosis } \\
\text { in DA neurons }\end{array}$ & $\begin{array}{l}\text { SHEDs-derived EVs, } \\
\sim 50-1000 \mathrm{~nm}\end{array}$ & $\begin{array}{l}\text { Co-culture of DA neurons with EVs, } \\
\text { for } 20 \mathrm{~h}\end{array}$ & $\begin{array}{l}\text { Suppressed 6-OHDA induced } \\
\text { apoptosis }\end{array}$ & $\begin{array}{l}\text { Jarmalavičiute } \\
\text { et al., } 2015\end{array}$ \\
\hline $\begin{array}{l}\text { Cortical neurons and DA } \\
\text { neurons from mouse pups }\end{array}$ & $\begin{array}{l}\text { Macrophages - derived EVs } \\
\text { incorporating therapeutic } \\
\text { protein catalase, } \\
\sim 100-200 \mathrm{~nm}\end{array}$ & $\begin{array}{l}\text { Co-culture of cortical neurons and DA } \\
\text { neurons with EVs, } 100 \mu \mathrm{g} / \mathrm{mL} \text { total } \\
\text { protein, for } 24 \mathrm{~h}\end{array}$ & Reduced ROS level & Haney et al., 2015 \\
\hline $\begin{array}{l}\text { 6-OHDA lesion of C57BL/6 } \\
\text { mice }\end{array}$ & & $\begin{array}{l}2.4 \times 10^{10} \mathrm{EVs} \text { in } 20 \mu \mathrm{l} \mathrm{PBS} / \text { mouse, } \\
\text { intranasally or intravenously }\end{array}$ & $\begin{array}{l}\text { Anti-inflammatory effect, reduced } \\
\text { microgliosis }\end{array}$ & \\
\hline \multicolumn{5}{|c|}{ AMYOTROPHIC LATERAL SCLEROSIS } \\
\hline $\begin{array}{l}\text { NSC-34 cells expressing } \\
\text { ALS mutations }\end{array}$ & $\begin{array}{l}\text { ADSC-derived EVs, } \\
30-120 \mathrm{~nm}\end{array}$ & $\begin{array}{l}\text { Co-culture of NSC-34 cells with } \\
200 \mu \mathrm{g} / \mathrm{ml} \mathrm{EVs} \text { for up to } 18 \mathrm{~h}\end{array}$ & $\begin{array}{l}\text { Protected cells from oxidative } \\
\text { damage }\end{array}$ & $\begin{array}{l}\text { Bonafede et al., } \\
2016\end{array}$ \\
\hline $\begin{array}{l}\text { G93A primary neuronal cell } \\
\text { culture }\end{array}$ & $\begin{array}{l}\text { AD-MSC-derived EVs, } \\
\sim 100 \mathrm{~nm}\end{array}$ & $\begin{array}{l}\text { Co-culture of G93A cells with } \\
200 \mu \mathrm{g} / \mathrm{ml} \text { EVs, twice on day } 2 \text { and } \\
\text { day } 6\end{array}$ & Reduced mutant SOD1 aggregation & Lee et al., 2016 \\
\hline \multicolumn{5}{|l|}{ STROKE } \\
\hline $\mathrm{MCAO}$ in rats & $\begin{array}{l}\text { BM-MSC-derived EVs, } \\
\sim 100 \mathrm{~nm}\end{array}$ & $\begin{array}{l}100 \mu \mathrm{g} \text { total protein of EVs in } 500 \mu \mathrm{l} \\
\text { PBS/rats, intravenously }\end{array}$ & $\begin{array}{l}\text { Improved functional recovery and } \\
\text { enhanced neurite remodeling, } \\
\text { neurogenesis, and angiogenesis }\end{array}$ & Xin et al., $2013 a$ \\
\hline MCAO in mice & $\begin{array}{l}\text { BM-MSC-derived EVs, } \\
\sim 100 \mathrm{~nm}\end{array}$ & $\begin{array}{l}\text { EVs released by } 2 \times 10^{6} \mathrm{MSCs} \\
\text { diluted in } 250 \mu \mathrm{l} \text { of saline, } \\
\text { intravenously }\end{array}$ & $\begin{array}{l}\text { Reduced post-ischemic motor } \\
\text { coordination impairment, induced } \\
\text { long-term neuroprotection, increased } \\
\text { cell proliferation, stimulated } \\
\text { neurogenesis, and angiogenesis }\end{array}$ & $\begin{array}{l}\text { Doeppner et al., } \\
2015\end{array}$ \\
\hline
\end{tabular}


TABLE 1 | Continued

\begin{tabular}{|c|c|c|c|c|}
\hline Disease model & Source of EVs & Protocol details & Reported effects & Reference \\
\hline $\mathrm{MCAO}$ in rats & $\begin{array}{l}\text { AD-MSC-derived EVs, } \\
\sim 100 \mathrm{~nm}\end{array}$ & $100 \mu \mathrm{g}$ EVs/rat, intravenously & $\begin{array}{l}\text { Reduced infiltration of } \mathrm{CD} 11^{+} \text {and } \\
\mathrm{CD}^{+}{ }^{+} \text {cells, decreased oxidative } \\
\text { stress, increased angiogenesis }\end{array}$ & Chen et al., 2016a \\
\hline Subcortical Stroke & $\begin{array}{l}\text { AD-MSC-derived EVs, } \\
\sim 100 \mathrm{~nm}\end{array}$ & $\begin{array}{l}100 \mu \mathrm{g} \text { total protein of EVs, } \\
\text { intravenously }\end{array}$ & $\begin{array}{l}\text { Rescued cognitive impairments, } \\
\text { improved functional recovery and } \\
\text { increased axonal sprouting }\end{array}$ & $\begin{array}{l}\text { Otero-Ortega } \\
\text { et al., } 2017\end{array}$ \\
\hline \multicolumn{5}{|l|}{ NEUROTRAUMA } \\
\hline $\begin{array}{l}\mathrm{TBI} \text { (controlled cortical } \\
\text { impact, CCI) in rat }\end{array}$ & $\begin{array}{l}\text { BM-MSC-derived EVs, } \\
\sim 100-150 \mathrm{~nm}\end{array}$ & $\begin{array}{l}100 \mu \mathrm{g} \text { total protein of EVs in } 500 \mu \mathrm{l} \\
\text { PBS/rat, intravenously }\end{array}$ & $\begin{array}{l}\text { Significantly improved spatial learning, } \\
\text { sensorimotor functional recovery, } \\
\text { reduced neuroinflammation, } \\
\text { increased the number of newly } \\
\text { formed mature neurons in the DG, } \\
\text { increased the number of newly } \\
\text { formed endothelial cells in the lesion } \\
\text { boundary zone and DG }\end{array}$ & $\begin{array}{l}\text { Zhang et al., 2015, } \\
2017\end{array}$ \\
\hline $\begin{array}{l}\text { TBI (controlled cortical } \\
\text { impact, CCI) in mice }\end{array}$ & $\begin{array}{l}\text { BM-MSC-derived EVs, } \\
\sim 200 \mathrm{~nm}\end{array}$ & $\begin{array}{l}30 \mu \mathrm{g} \text { total protein of EVs }(15 \times \\
\left.10^{9}\right) / \text { mice, single intravenous injection }\end{array}$ & Rescued cognitive impairments & Kim et al., 2016 \\
\hline Contused SCl in rat & $\begin{array}{l}\text { BM-MSC-derived EVs, } \\
\sim 20-130 \mathrm{~nm}\end{array}$ & $\begin{array}{l}100 \mu \mathrm{g} \text { total protein of EVs }(1 \times \\
\left.10^{10}\right) \text { in } 500 \mu \mathrm{l} \text { PBS/rat, intravenously }\end{array}$ & $\begin{array}{l}\text { Decreased expression of } \\
\text { proapoptotic protein (Bax) and } \\
\text { pro-inflammatory cytokines (TNF- } \alpha \\
\text { and IL-1 } \beta \text { ), increased expression } \\
\text { levels of anti-apoptotic (Bcl-2) and } \\
\text { anti-inflammatory (IL-10) proteins }\end{array}$ & Huang et al., 2017 \\
\hline Contused $\mathrm{SCl}$ in rat & $\begin{array}{l}\text { BM-MSC-derived EVs, } \\
\sim 30-150 \mathrm{~nm}\end{array}$ & $\begin{array}{l}40 \mu \mathrm{g} \text { total protein of EVs }\left(1 \times 10^{6}\right) \text { in } \\
200 \mu \mathrm{L} \mathrm{PBS} / \text { rat, } 30 \text { min and } 1 \text { day } \\
\text { post-SCl, intravenously }\end{array}$ & $\begin{array}{l}\text { Reduced the proportion of } \mathrm{A} 1 \\
\text { astrocytes, decreased lesion area and } \\
\text { expression of pro-inflammatory } \\
\text { cytokines (TNF } \alpha, \mathrm{IL}-1 \alpha, \mathrm{IL}-1 \beta) \text {, } \\
\text { improved functional recovery }\end{array}$ & Wang et al., 2018 \\
\hline Contused $\mathrm{SCl}$ in rat & BM-MSC-derived EVs & $\begin{array}{l}1 \times 10^{9} \text { of EVs in } 1 \mathrm{ml} \mathrm{PBS} / \text { rat, } 3 \mathrm{~h} \\
\text { post-SCl, intravenously }\end{array}$ & $\begin{array}{l}\text { Reduced neuroinflammation, } \\
\text { decreased reactive microglia and } \\
\text { astrocytes, improved functional } \\
\text { recovery }\end{array}$ & $\begin{array}{l}\text { Ruppert et al., } \\
2018\end{array}$ \\
\hline Contused $\mathrm{SCl}$ in rat & $\begin{array}{l}\text { BM-MSC- derived EVs, } \\
\sim 30-100 \mathrm{~nm}\end{array}$ & $\begin{array}{l}2.5 \times 10^{9} \text { in } 200 \mu \mathrm{l} \mathrm{PBS} / \text { rat, } \\
\text { intravenously }\end{array}$ & $\begin{array}{l}\text { Targeted the SCI site and might } \\
\text { contribute to the therapeutic effects, } \\
\text { target specifically to } \mathrm{M} 2 \text { macrophages }\end{array}$ & $\begin{array}{l}\text { Lankford et al., } \\
2018\end{array}$ \\
\hline
\end{tabular}

it was indicated that AD-MSC-derived EVs when transferred to N2a cells (a fast-growing mouse neuroblastoma cell line overproducing human $A \beta$ ) contributed, at least in part, to a decrease in both extracellular and intracellular $A \beta$ levels. That AD-MSCs expressed NEP at a higher level than BM-MSCs is an important observation highlighting the importance of MSC origin on function (Yasojima et al., 2001).

An alternative cellular source of EVs for therapeutic intervention in $\mathrm{AD}$ were used by Yuyama et al. (2015). These authors showed that intracerebral infusion of neuronal EVs into brains of APP transgenic mice decreased amyloid depositions, suggesting an important role for neuronal exosomes in clearing $A \beta$ in brain, but not explaining mechanisms of EVs actions.

\section{Parkinson's Disease (PD)}

Haney et al. (2015) proposed a new EV-based technology for catalase delivery to the CNS to treat PD. Bovine liver derived catalase was loaded into EVs isolated from the mouse macrophage cell line (Raw 264.7). The in vitro study data demonstrated that reactive oxygen species (ROS) levels decreased when catalase-loaded EVs as well as empty ones were co-cultured with cortical neurons and dopaminergic (DA) neurons, although the effect of empty EVs was less significant. Administration of the same catalase loaded EVs to a model of 6-OHDA lesions in C57BL/6 female mice had an anti-inflammatory effect manifested as decreased microgliosis. It is important to note that there was no effect on microglia activation, or the number of DA neurons. It was hypothesized that EVs-mediated delivery of catalase to activated microglia, astrocytes, and neurons in the inflamed brain might result in ROS degradation and neuroprotection in PD patients.

Jarmalavičiute et al. (2015) demonstrated in vitro that EVs isolated from the supernatants of stem cells derived from the dental pulp of human exfoliated deciduous teeth (SHEDs), and grown on laminin-coated 3D alginate micro-carriers, suppressed 6-OHDA (6-hydroxy-dopamine) induced apoptosis in DA neurons. Interestingly, EVs from the same stem cells cultured under standard conditions possessed no such properties. These results confirm that EVs serve as a novel therapeutic approach in the treatment of Parkinson's disease, although the mechanism of action remains unclear. 


\section{Amyotrophic Lateral Sclerosis (ALS)}

Bonafede et al. (2016) showed in vitro, that AD-stromal cell-derived EVs (AD-SC-derived EVs) were able to protect NSC-34 cells from oxidative damage, which is one of the main mechanisms of damage in ALS, increasing cell viability. They suggest the positive effect might be caused by secretion of miRNAs, which play a protective role via inhibition of apoptosis pathways, and promoting cell cycle progression and proliferation. AD-SC-derived EVs were shown in vitro to ameliorate SOD1 protein levels and aggregates in neuronal cells derived from G93A ALS mice. It was concluded that the abnormal expression of mitochondrial proteins in ALS cells could be rescued by application of AD-SC-derived EVs (Lee et al., 2016).

\section{Stroke}

When using BM-MSC-derived EVs in a model of middle cerebral artery occlusion (MCAO) ischemic lesion volumes reduced, however there was no significant difference compared to PBStreated controls (Xin et al., 2013a). This study demonstrated that neurite remodeling improved, alongside increases in synaptic plasticity, neurogenesis and angiogenesis within the ischemic boundary zone. These improvements in function were proposed to be the result of miR133b activity on neurite remodeling, delivered to neural cells as part of the BM-MSC-derived EVs cargo (Xin et al., 2013b). In complementary study, intravenous injection of BM-MSC-derived EVs into an in vivo model of MCAO reduced post-ischemic motor coordination impairment, induced long-term neuroprotection, increased cell proliferation, and stimulated neurogenesis and angiogenesis (Doeppner et al., 2015).

Chen et al. (2016a) studied the effects of intravenous administration of AD-MSC-derived EVs and AD-MSCs in a model of MCAO. Results demonstrated that neurological impairment was reversed after treatment with AD-MSC-derived EVs an effect that was more significant when treatment used AD-MSCs. Reduced infiltration of CD11+ and CD68+ cells (two indicators of inflammation), decreased oxidative stress and increased angiogenesis were reported in both experimental groups.

Otero-Ortega et al. (2017) demonstrated in a model of subcortical stroke that after intravenous infusion, EVs were found in the brain and peripheral organs (the liver, lungs and the spleen). There was improved functional outcome, increased axonal sprouting, increased oligodendrocyte-associated marker expression and myelin formation, changes in white matter thickness and the restoration of tract connectivity at 28 days after EV administration. Proteomics analysis of the EVs identified 2,416 proteins that are implicated in repairing brain functions.

\section{Neurotrauma}

Zhang et al. (2015) demonstrated that BM-MSC-derived EVs effectively improved functional outcome by promoting endogenous angiogenesis, neurogenesis and reducing inflammation in rats after traumatic brain injury (TBI). In 2 years the same team of scientists reported the results of systemic administration of BM-MSC-derived EVs cultured under $2 \mathrm{D}$ and $3 \mathrm{D}$ conditions. This treatment did not alter cortical lesion volume but significantly improved cognitive and sensorimotor functional recovery, increased the number of newly formed mature neurons in the dentate gyrus (DG). It also increased the number of newly formed endothelial cells in the lesion boundary zone and DG, as well as reduced neuroinflammation. BM-MSC-derived EVs cultured under 3D conditions provided better outcome in spatial learning compared to EVs from a 2D culture (Zhang et al., 2017).

Kim et al. (2016) demonstrated that BM-MSC-derived EVs suppressed neuroinflammation after TBI in mice. It was also shown that an intravenous infusion of the isolated EVs shortly after induction of TBI rescued pattern separation and spatial learning impairments 1 month later.

Studies of the therapeutic potential of EVs in spinal cord injury (SCI) report that systemic administration of BMMSC-derived EVs in contused SCI in rats attenuated cell apoptosis and inflammatory processes, stimulated angiogenesis, and promoted functional recovery. In particular, there was a downregulated expression of a pro-apoptotic protein (Bax) and pro-inflammatory cytokines (TNF- $\alpha$ and IL-1 $\beta$ ), increased expression levels of anti-apoptotic (Bcl-2) and anti-inflammatory (IL-10) proteins (Huang et al., 2017). Furthermore, Lankford et al. (2018) demonstrated that intravenously delivered BMMSC-derived EVs targeted the SCI site, might contribute to the therapeutic effects by specifically targeting M2 macrophages. EVs were detected in the area of SCI and the spleen, but not in the intact region of the spinal cord.

Recently, Wang et al. (2018) confirmed a comparable therapeutic effect of intravenously administered BM-MSCderived EVs and BM-MSCs in SCI. The authors observed that BM-MSC-derived EVs reduced the proportion of neurotoxic astrocytes, probably via inhibiting nuclear translocation of NFKB p65, and exerted anti-inflammatory and neuroprotective effects following SCI. Similar results were obtained by Ruppert et al. (2018), who confirmed the anti-inflammatory and functional effects of intravenously delivered BM-MSC-derived EVs by means of a decreased in microglia activation markers rather than skewing microglial polarization.

\section{Clinical Trials Using EVS in the Treatment of Nerve Disorders}

The conceptual advance in our understanding of the therapeutic application of EVs as a regenerative strategy for neural tissue is relatively new. Therefore, a considerable number of studies are non-clinical, relying on in vitro and in vivo models. To date the Food and Drug Administration (FDA) have approved clinical trials using EVs as a treatment of ulcers (ClinicalTrials.gov Identifier: NCT02565264), sepsis (NCT02957279), macular hole (NCT03437759), and type 1 diabetes mellitus (NCT02138331). Based on pre-clinical studies of EV-mediated delivery of miR124 promoting neurogenesis after ischemia (Yang et al., 2017), a further clinical trial using MSC-derived EVs in the treatment of acute ischemic stroke (NCT03384433) is planned for 2018-19, in which the effect of MSC-generated EVs will be examined in post-stroke phases 1 and 2 . 


\section{CONCLUSION}

Studies of the therapeutic potential of EVs in regenerative strategies strongly support the use of MSC-derived EVs in the treatment of nerve tissue disorders. MSC-derived EVs are reported to exert the majority of the positive effects seen with the direct use of MSCs as a therapy, but without the risks associated with stem cell transplantation (Gatti et al., 2011; Li et al., 2012; Konala et al., 2016). The rapid progression from non-clinical to clinical studies of MSC-derived EVs will uncover the exciting potential that EV-mediated cell free therapy may offer for the treatment of nerve disorders.

\section{AUTHOR CONTRIBUTIONS}

LG: collection of data on the characteristics of immunomodulatory and neuroprotective effects of EVs,

\section{REFERENCES}

Akers, J. C., Gonda, D., Kim, R., Carter, B. S., and Chen, C. C. (2013). Biogenesis of extracellular vesicles (EV): exosomes, microvesicles, retrovirus-like vesicles, and apoptotic bodies. J. Neuro Oncol. 113, 1-11. doi: 10.1007/s11060-013-1084-8

Alvarez-Erviti, L., Seow, Y., Yin, H., Betts, C., Lakhal, S., and Wood, M. J. (2011). Delivery of siRNA to the mouse brain by systemic injection of targeted exosomes. Nat. Biotechnol. 29:341. doi: 10.1038/nb t. 1807

Bi, B., Schmitt, R., Israilova, M., Nishio, H., and Cantley, L. G. (2007). Stromal cells protect against acute tubular injury via an endocrine effect. J. Am. Soc. Nephrol. 18, 2486-2496. doi: 10.1681/ASN.2007020140

Biancone, L., Bruno, S., Deregibus, M. C., Tetta, C., and Camussi, G. (2012). Therapeutic potential of mesenchymal stem cell-derived microvesicles. Nephrol. Dialysis Transplant. 27, 3037-3042. doi: 10.1093/ndt/gfs 168

Blazquez, R., Sanchez-Margallo, F. M., de la Rosa, O., Dalemans, W., Alvarez, V., Tarazona, R., et al. (2014). Immunomodulatory potential of human adipose mesenchymal stem cells derived exosomes on in vitro stimulated T cells. Front. Immunol. 5:556. doi: 10.3389/fimmu.2014.00556

Bobrie, A., Colombo, M., Raposo, G., and Théry, C. (2011). Exosome secretion: molecular mechanisms and roles in immune responses. Traffic 12, 1659-1668. doi: 10.1111/j.1600-0854.2011.01225.x

Bonafede, R., Scambi, I., Peroni, D., Potrich, V., Boschi, F., Benati, D., et al. (2016). Exosome derived from murine adipose-derived stromal cells: neuroprotective effect on in vitro model of amyotrophic lateral sclerosis. Exp. Cell Res. 340, 150-158. doi: 10.1016/j.yexcr.2015.12.009

Börger, V., Bremer, M., Ferrer-Tur, R., Gockeln, L., Stambouli, O., Becic, A., et al. (2017). Mesenchymal stem/stromal cell-derived extracellular vesicles and their potential as novel immunomodulatory therapeutic agents. Int. J. Mol. Sci. 18:1450. doi: 10.3390/ijms18071450

Braccioli, L., van Velthoven, C., and Heijnen, C. J. (2014). Exosomes: a new weapon to treat the central nervous system. Mol. Neurobiol. 49, 113-119. doi: 10.1007/s12035-013-8504-9

Bruno, S., Deregibus, M. C., and Camussi, G. (2015). The secretome of mesenchymal stromal cells: role of extracellular vesicles in immunomodulation. Immunol. Lett. 168, 154-158. doi: 10.1016/j.imlet.2015.06.007

Bruno, S., Grange, C., Deregibus, M. C., Calogero, R. A., Saviozzi, S., Collino, F., et al. (2009). Mesenchymal stem cell-derived microvesicles protect against acute tubular injury. J. Am. Soc. Nephrol. 20, 1053-1067. doi: 10.1681/ASN.2008070798

Camussi, G., Deregibus, M. C., and Cantaluppi, V. (2013). Role of stem-cellderived microvesicles in the paracrine action of stem cells. Biochem. Soc. Trans. 41, 283-287. doi: 10.1042/BST20120192 compilation these data. VJ: collection of data on the transplantation EVs in neurodegeneration deseases, professional English editing. YM: collection of data on the transplantation EVs in stroke and traumatic injury, compilation these data, drawing Figure 1. AR: compilation of article content, writing some chapters.

\section{FUNDING}

This work was supported by a grant from the Russian Science Foundation No. 18-75-00043 YM. This work was performed in accordance with the Program of Competitive Growth of the Kazan Federal University and a subsidy allocated to the Kazan Federal University for the state assignment in the sphere of scientific activities. AR was supported by a state assignment 20.5175.2017/6.7 (Leading Researcher) of the Ministry of Education and Science of the Russian Federation.

Chaput, N., and Théry, C. (2011). Exosomes: immune properties and potential clinical implementations. Semin. Immunopathol. 33, 419-440. doi: 10.1007/s00281-010-0233-9

Chen, K. H., Chen, C. H., Wallace, C. G., Yuen, C. M., Kao, G. S., Chen, Y. L., et al. (2016a). Intravenous administration of xenogenic adipose-derived mesenchymal stem cells (ADMSC) and ADMSC-derived exosomes markedly reduced brain infarct volume and preserved neurological function in rat after acute ischemic stroke. Oncotarget 7, 74537-74556. doi: 10.18632/oncotarget.12902

Chen, W., Huang, Y., Han, J., Yu, L., Li, Y., Lu, Z., et al. (2016b). Immunomodulatory effects of mesenchymal stromal cells-derived exosome. Immunol. Res. 64, 831-840. doi: 10.1007/s12026-016-8798-6

Collino, F., Pomatto, M., Bruno, S., Lindoso, R. S., Tapparo, M., Sicheng, W., et al. (2017). Exosome and microvesicle-enriched fractions isolated from mesenchymal stem cells by gradient separation showed different molecular signatures and functions on renal tubular epithelial cells. Stem Cell Rev. Rep. 13, 226-243. doi: 10.1007/s12015-016-9713-1

Confavreux, C., Hutchinson, M., Hours, M. M., Cortinovi,-Tourniaire, P., and Moreau, T. (1998). Rate of pregnancy-related relapse in multiple sclerosis. Pregnancy in multiple sclerosis group. N. Engl. J. Med. 339, 285-291. doi: 10.1056/NEJM199807303390501

Conforti, A., Scarsella, M., Starc, N., Giorda, E., Biagini, S., Proia, A., et al. (2014). Microvescicles derived from mesenchymal stromal cells are not as effective as their cellular counterpart in the ability to modulate immune responses in vitro. Stem Cells Dev. 23, 2591-2599. doi: 10.1089/scd.2014.0091

Del Fattore, A., Luciano, R., Pascucci, L., Goffredo, B. M., Giorda, E., Scapaticci, M., et al. (2015). Immunoregulatory effects of mesenchymal stem cell-derived extracellular vesicles on $\mathrm{T}$ lymphocytes. Cell Transplant. 24, 2615-2627. doi: 10.3727/096368915X687543

Doeppner, T. R., Herz, J., Görgens, A., Schlechter, J., Ludwig, A. K., Radtke, S., et al. (2015). Extracellular vesicles improve post-stroke neuroregeneration and prevent postischemic immunosuppression. Stem Cells Transl. Med. 4, 1131-1143. doi: 10.5966/sctm.2015-0078

Dugas, J. C., Cuellar, T. L., Scholze, A., Ason, B., Ibrahim, A., Emery, B., et al. (2010). Dicer1 and miR-219 Are required for normal oligodendrocyte differentiation and myelination. Neuron 65, 597-611. doi: 10.1016/j.neuron.2010.01.027

Gatti, S., Bruno, S., Deregibus, M. C., Sordi, A., Cantaluppi, V., Tetta, C., et al. (2011). Microvesicles derived from human adult mesenchymal stem cells protect against ischaemia-reperfusion-induced acute and chronic kidney injury. Nephrology Dialysis Transplant. 26, 1474-1483. doi: 10.1093/ndt/gfr015

Gnecchi, M., He, H., Liang, O. D., Melo, L. G., Morello, F., Mu, H., et al. (2005). Paracrine action accounts for marked protection of ischemic heart by Aktmodified mesenchymal stem cells. Nat. Med. 11:367. doi: 10.1038/nm0405-367 
Gnecchi, M., He, H., Noiseux, N., Liang, O. D., Zhang, L., Morello, F., et al. (2006). Evidence supporting paracrine hypothesis for Akt-modified mesenchymal stem cell-mediated cardiac protection and functional improvement. FASEB J. 20, 661-669. doi: 10.1096/fj.05-5211com

Gomzikova, M. O., and Rizvanov, A. A. (2017). Current trends in regenerative medicine: from cell to cell-free therapy. BioNanoScience 7, 240-245. doi: 10.1007/s12668-016-0348-0

Haney, M. J., Klyachko, N. L., Zhao, Y., Gupta, R., Plotnikova, E. G., He, Z., et al. (2015). Exosomes as drug delivery vehicles for Parkinson's disease therapy. J. Controlled Release 207, 18-30. doi: 10.1016/j.jconrel.2015.03.033

Harting, M. T., Srivastava, A. K., Zhaorigetu, S., Bair, H., Prabhakara, K. S., Toledano Furman, N. E., et al. (2018). Inflammation-stimulated mesenchymal stromal cell-derived extracellular vesicles attenuate inflammation. Stem Cells 36, 79-90. doi: 10.1002/stem.2730

Huang, J. H., Yin, X. M., Xu, Y., Xu, C. C., Lin, X., Ye, F. B., et al. (2017). Systemic administration of exosomes released from mesenchymal stromal cells attenuates apoptosis, inflammation, and promotes angiogenesis after spinal cord injury in rats. J. Neurotrauma 34, 3388-3396. doi: 10.1089/neu.2017.5063

Iwata, N., Tsubuki, S., Takaki, Y., Watanabe, K., Sekiguchi, M., Hosoki, E., et al. (2000). Identification of the major $A \beta$ 1-42-degrading catabolic pathway in brain parenchyma: suppression leads to biochemical and pathological deposition. Nat. Med. 6, 143-150. doi: 10.1038/72237

Jarmalavičiute, A., Tunaitis, V., Pivorait,e, U., Venalis, A., and Pivoriunas, A. (2015). Exosomes from dental pulp stem cells rescue human dopaminergic neurons from 6-hydroxy-dopamine-induced apoptosis. Cytotherapy 17, 932-939. doi: 10.1016/j.jcyt.2014.07.013

Junker, A., Krumbholz, M., Eisele, S., Mohan, H., Augstein, F., Bittner, R., et al. (2009). MicroRNA profiling of multiple sclerosis lesions identifies modulators of the regulatory protein CD47. Brain 132(Pt 12):3342-3352. doi: 10.1093/brain/awp300

Kalani, A., Tyagi, A., and Tyagi, N. (2014). Exosomes: mediators of neurodegeneration, neuroprotection and therapeutics. Mol. Neurobiol. 49, 590-600. doi: 10.1007/s12035-013-8544-1

Katsuda, T., Tsuchiya, R., Kosaka, N., Yoshioka, Y., Takagaki, K., Oki, K., et al. (2013). Human adipose tissue-derived mesenchymal stem cells secrete functional neprilysin-bound exosomes. Sci. Rep. 3:1197. doi: 10.1038/srep01197

Kim, D. K., Nishida, H., An, S. Y., Shetty, A. K., Bartosh, T. J., and Prockop, D. J. (2016). Chromatographically isolated CD63+ CD81+ extracellular vesicles from mesenchymal stromal cells rescue cognitive impairments after TBI. Proc. Natl. Acad. Sci. U.S.A. 113, 170-175. doi: 10.1073/pnas.1522297113

Konala, V. B., Mamidi, M. K., Bhonde, R., Das, A. K., Pochampally, R., Pal, R., et al. The current landscape of the mesenchymal stromal cell secretome: a new paradigm for cell-free regeneration., Cytotherapy (2016). 18, 13-24. doi: $10.1016 /$ j.jcyt.2015.10.008

Koniusz, S., Andrzejewska, A., Muraca, M., Srivastava, A. K., Janowski, M., and Lukomska, B. (2016). Extracellular vesicles in physiology, pathology, and therapy of the immune and central nervous system, with focus on extracellular vesicles derived from mesenchymal stem cells as therapeutic tools. Front. Cell. Neurosci. 10:109. doi: 10.3389/fncel.2016.00109

Lai, R. C., Arslan, F., Lee, M. M., Sze, N. S., Choo, A., Chen, T. S., et al. (2010). Exosome secreted by MSC reduces myocardial ischemia/reperfusion injury. Stem Cell Res. 4, 214-222. doi: 10.1016/j.scr.2009.12.003

Lankford, K. L., Arroyo, E. J., Nazimek, K., Bryniarski, K., Askenase, P. W., and Kocsis, J. D. (2018). Intravenously delivered mesenchymal stem cell-derived exosomes target M2-type macrophages in the injured spinal cord. PLoS ONE 13:e0190358. doi: 10.1371/journal.pone.0190358

Lee, M., Ban, J. J., Kim, K. Y., Jeon, G. S., Im, W., Sung, J. J., et al. (2016). Adipose-derived stem cell exosomes alleviate pathology of amyotrophic lateral sclerosis in vitro. Biochem. Biophys. Res. Commun. 479, 434-439. doi: 10.1016/j.bbrc.2016.09.069

Li, T., Yan, Y., Wang, B., Qian, H., Zhang, X., Shen, L., et al. (2012). Exosomes derived from human umbilical cord mesenchymal stem cells alleviate liver fibrosis. Stem Cells Dev. 22, 845-854. doi: 10.1089/scd.2012.0395

Ma, Y., Bao-Han, W., Lv, X., Su, Y., Zhao, X., Yin, Y., et al. (2013). MicroRNA-34a mediates the autocrine signaling of PAR2-activating proteinase and its role in colonic cancer cell proliferation. PLOS ONE 8:e72383. doi: 10.1371/journal.pone. 0072383
Mokarizadeh, A., Delirezh, N., Morshedi, A., Mosayebi, G., Farshid, A. A., and Mardani, K. (2012). Microvesicles derived from mesenchymal stem cells: potent organelles for induction of tolerogenic signaling. Immunol. Lett. 147, 47-54. doi: 10.1016/j.imlet.2012.06.001

Otero-Ortega, L., Laso-García, F., Gómez-de Frutos, M. D., Rodríguez-Frutos, B., Pascual-Guerra, J., Fuentes, B., et al. (2017). White matter repair after extracellular vesicles administration in an experimental animal model of subcortical stroke. Sci. Rep. 7:44433. doi: 10.1038/srep44433

Parekkadan, B., van Poll, D., Suganuma, K., Carter, E. A., Berthiaume, F., Tilles, A. W., et al. (2007). Mesenchymal stem cell-derived molecules reverse fulminant hepatic failure. PLoS ONE 2:e941. doi: 10.1371/journal.pone.0000941

Pusic, A. D., and Kraig, R. P. (2014b). Youth and environmental enrichment generate serum exosomes containing miR-219 that promote CNS myelination. Glia 62, 284-299. doi: 10.1002/glia.22606

Pusic, A. D., Pusic, K. M., Clayton, B. L., and Kraig, R. P. (2014c). IFN $\gamma$ stimulated dendritic cell exosomes as a potential therapeutic for remyelination. J. Neuroimmunol. 266, 12-23. doi: 10.1016/j.jneuroim.2013.10.014

Pusic, A. D., Pusic, K. M., and Kraig, R. P. (2014a). What are exosomes and how can they be used in multiple sclerosis therapy? Expert Rev. Neurother. (2014) 14, 353-355. doi: 10.1586/14737175.2014.890893

Reiner, A. T., Witwer, K. W., van Balkom, B. W. M., de Beer, J., Brodie, C., Corteling, R. L., et al. (2017). Concise review: developing best-practice models for the therapeutic use of extracellular vesicles. Stem Cells Transl. Med. 6, 1730-1739. doi: 10.1002/sctm.17-0055

Ruppert, K. A., Nguyen, T. T., Prabhakara, K. S., Toledano Furman, N. E., Srivastava, A. K., Harting, M. T., et al. (2018). Human mesenchymal stromal cell-derived extracellular vesicles modify microglial response and improve clinical outcomes in experimental spinal cord injury. Sci. Rep. 8:480. doi: 10.1038/s41598-017-18867-w

Selmaj, I., Mycko, M. P., Raine, C. S., and Selmaj, K. W. (2017). The role of exosomes in CNS inflammation and their involvement in multiple sclerosis. J. Neuroimmunol. 306, 1-10. doi: 10.1016/j.jneuroim.2017.02.002

Takahashi, M., Li, T. S., Suzuki, R., Kobayashi, T., Ito, H., Ikeda, Y., et al. (2006). Cytokines produced by bone marrow cells can contribute to functional improvement of the infarcted heart by protecting cardiomyocytes from ischemic injury. Am. J. Physiol. Heart Circul. Physiol. 291, H886-H893. doi: 10.1152/ajpheart.00142.2006

Taylor, D. D., and Gercel-Taylor, C. (2011). Exosomes/microvesicles: mediators of cancer-associated immunosuppressive microenvironments. Semin. Immunopathol. 33, 441-454. doi: 10.1007/s00281-010-0234-8

Timmers, L., Lim, S. K., Arslan, F., Armstrong, J. S., Hoefer, I. E., Doevendans, P. A., et al. (2007). Reduction of myocardial infarct size by human mesenchymal stem cell conditioned medium. Stem Cell Res. 1, 129-137. doi: 10.1016/j.scr.2008.02.002

Vallabhaneni, K. C., Penfornis, P., Dhule, S., Guillonneau, F., Adams, K. V., Mo, Y. Y., et al. (2015). Extracellular vesicles from bone marrow mesenchymal stem/stromal cells transport tumor regulatory microRNA, proteins, and metabolites. Oncotarget 6:4953. doi: 10.18632/oncotarget.3211

Verma, P., Augustine, G. J., Ammar, M. R., Tashiro, A., and Cohen, S. M. (2015). A neuroprotective role for microRNA miR-1000 mediated by limiting glutamate excitotoxicity. Nat. Neurosci. 18:379. doi: 10.1038/nn.3935

Wang, L., Pei, S., Han, L., Guo, B., Li, Y., Duan, R., et al. (2018). Mesenchymal stem cell-derived exosomes reduce Al astrocytes via downregulation of phosphorylated NFkB P65 subunit in spinal cord injury. Cell Physiol. Biochem. 50, 1535-1559. doi: 10.1159/000494652

Wang, S. S., Jia, J., and Wang, Z. (2017). Mesenchymal stem cell-derived extracellular vesicles suppresses iNOS expression and ameliorates neural impairment in Alzheimer's disease mice. J. Alzheimer's Dis. 61, 1005-1013. doi: $10.3233 / J A D-170848$

Williams, J. L., Gatson, N. N., Smith, K. M., Almad, A., McTigue, D. M., Whitacre, C. C., et al. (2013). Serum exosomes in pregnancy-associated immune modulation and neuroprotection during CNS autoimmunity. Clin. Immunol. 149, 236-243. doi: 10.1016/j.clim.2013.04.005

Xin, H., Li, Y., Cui, Y., Yang, J. J., Zhang, Z. G., and Chopp, M. (2013a). Systemic administration of exosomes released from mesenchymal stromal cells promote functional recovery and neurovascular plasticity after stroke in rats. J. Cereb. Blood Flow Metab. 33, 1711-1715. doi: 10.1038/jcbfm.2013.152 
Xin, H., Li, Y., Liu, Z., Wang, X., Shang, X., Cui, Y., et al. (2013b). MiR$133 \mathrm{~b}$ promotes neural plasticity and functional recovery after treatment of stroke with multipotent mesenchymal stromal cells in rats via transfer of exosome-enriched extracellular particles. Stem Cells 31, 2737-2746. doi: 10.1002/stem.1409

Yang, J., Zhang, X., Chen, X., Wang, L., and Yang, G. (2017). Exosome mediated delivery of miR-124 promotes neurogenesis after ischemia. Mol. Ther. Nucleic Acids. 7, 278-287. doi: 10.1016/j.omtn.2017.04.010

Yasojima, K., Akiyama, H., McGeer, E. G., and McGeer, P. L. (2001). Reduced neprilysin in high plaque areas of Alzheimer brain: a possible relationship to deficient degradation of $\beta$-amyloid peptide. Neurosci. Lett. 297, 97-100. doi: 10.1016/S0304-3940(00)01675-X

Yu, L., Yang, F., Jiang, L., Chen, Y., Wang, K., Xu, F., et al. (2013). Exosomes with membrane-associated TGF- $\beta 1$ from gene-modified dendritic cells inhibit murine EAE independently of MHC restriction. Eur. J. Immunol. 43, 2461-2472. doi: 10.1002/eji.201243295

Yuyama, K., Sun, H., Usuki, S., Sakai, S., Hanamatsu, H., Mioka, T., et al. (2015). A potential function for neuronal exosomes: sequestering intracerebral amyloid- $\beta$ peptide. FEBS Lett. 589, 84-88. doi: 10.1016/j.febslet.2014.11.027

Zhang, B., Yeo, R. W., Tan, K. H., Lim, S. K., et al. (2016). Focus on extracellular vesicles: therapeutic potential of stem cell-derived extracellular vesicles. Int. J. Mol. Sci. 17:174. doi: 10.3390/ijms17020174

Zhang, B., Yin, Y., Lai, R. C., Tan, S. S., Choo, A. B., and Lim, S. K. (2014). Mesenchymal stem cells secrete immunologically active exosomes. Stem Cells Dev. 23, 1233-1244. doi: 10.1089/scd.2013.0479

Zhang, Y., Chopp, M., Meng, Y., Katakowski, M., Xin, H., Mahmood, A., et al. (2015). Effect of exosomes derived from multipluripotent mesenchymal stromal cells on functional recovery and neurovascular plasticity in rats after traumatic brain injury. J. Neurosurg. 122, 856-867. doi: 10.3171/2014.11.JNS14770

Zhang, Y., Chopp, M., Zhang, Z. G., Katakowski, M., Xin, H., Qu, C., et al. (2017). Systemic administration of cell-free exosomes generated by human bone marrow derived mesenchymal stem cells cultured under $2 \mathrm{D}$ and 3D conditions improves functional recovery in rats after traumatic brain injury. Neurochem. Int. 111, 69-81. doi: 10.1016/j.neuint.2016.08.003

Zhao, X., He, X., Han, X., Yu, Y., Ye, F., Chen, Y., et al. (2010). MicroRNAmediated control of oligodendrocyte differentiation. Neuron 65, 612-626. doi: 10.1016/j.neuron.2010.02.018

Zhuang, X., Xiang, X., Grizzle, W., Sun, D., Zhang, S., Axtell, R. C., et al. (2011). Treatment of brain inflammatory diseases by delivering exosome encapsulated anti-inflammatory drugs from the nasal region to the brain. Mol. Ther. 19, 1769-1779. doi: 10.1038/mt.2011.164

Conflict of Interest Statement: The authors declare that the research was conducted in the absence of any commercial or financial relationships that could be construed as a potential conflict of interest.

Copyright (c) 2019 Galieva, James, Mukhamedshina and Rizvanov. This is an openaccess article distributed under the terms of the Creative Commons Attribution License (CC BY). The use, distribution or reproduction in other forums is permitted, provided the original author(s) and the copyright owner(s) are credited and that the original publication in this journal is cited, in accordance with accepted academic practice. No use, distribution or reproduction is permitted which does not comply with these terms. 